\title{
The Effect of Solvent on the Oil Yield of Treculia Africana Seed Flour
}

\author{
Ipeghan Jonathan Otaraku, Yirakpoa Patience Nwambo, Ishioma Laurene Egun
}

\begin{abstract}
This paper looks at the extraction of oil from African Breadfruit (Treculia Africana) seeds using different solvents. The seeds were crushed into powder and the oil was extracted from the powder. The method of extraction employed was soxhlet (Solvent extraction method). The solvents used were Acetone, N-hexane, Ethanol, Petroleum Ether and Diethyl ether. The amount of oil extracted by each solvent was recorded and the \% yield was calculated.Conc. Diethyl ether had the highest \% yield of 15.02 while Ethanol had the lowest \% yield of 0.2. Also there was a significant difference in the yield of oil extracted byDiethyl ether and Conc. Diethyl ether showing that the concentration of a particular solvent has an effect on the quantity of oil yield.
\end{abstract}

Index Terms — Extraction, Solvent, Extracting Power, Seeds.

\section{INTRODUCTION}

Treculia Africana (African breadfruit) is a tropical tree crop belonging to member of the Moraceae family and is a native of the East Indies [1]. It is a large tree which grows in wet and forest areas of tropical Africa; it is generally cultivated in the tropics and its tree could grow up to be 40-50 ft high [2]. The seeds from the fruit are edible and are of high nutritional values [3]. It has been estimated that the fruit may contain as much as 1,500 seeds [4]. It was originally seen as a tropical rain forest plant, but presently, it is a well-known source of food, grown in compound farms, village settlement, plantations in most rain forest region and part of the derived savannah areas of Southern Nigeria, Angola, Sudan, Senegal, Sao Tome [5]. The crop is always grown from the seeds which must be planted when fairly fresh as they lose viability in few weeks. The seeds of the African breadfruit are of high nutritional value, the fruit bears seeds which are coated with a hard endocarp and the seeds contain oil.

There are several methods to extract oil from seeds such as pressing, solvent extraction and supercritical fluid extraction [6]. Soxhlet (solvent) extraction is the standard technique where the fresh solvent contacts the sample frequently [7]. It is widely used technique because it is simple and easy to run. Extraction depends on the nature of the solvent and oil, contact time of sample with solvent, extraction temperature, particle size and solvent ratio. It is required to select a suitable

Ipeghan Jonathan Otaraku, Department of Chemical Engineering, University of Port Harcourt, Port Harcourt, Nigeria

Yirakpoa Patience Nwambo, Department of Chemical Engineering, University of Port Harcourt, Port Harcourt, Nigeria

IshiomaLaureneEgun, Department of Chemical Engineering, University of Port Harcourt, Port Harcourt, Nigeria solvent for the extraction of oil. Hexane is a widely used solvent in oil extraction due to its low boiling temperature and low corrosiveness [6], Apart from hexane, other polar and non-polar solvents used for the oil extraction are petroleum ether [8], ethyl ether [7], pentane, isopropanol, toluene, ethyl acetate, cyclohexane, acetone, chloroform, ethanol $[9,10,11]$ and methanol [12]. But no detail data is available in the literature regarding oil extraction from castor seed with different solvents as well as their physico-chemical properties estimation. Therefore, the study has been conducted to compare the efficiency of oil extraction from castor seed by different solvents and their properties estimation.

\section{MATERIALS AND METHODS}

\section{A. Sample Preparation}

The matured fruit head of the African breadfruit (Treculia Africana) was harvested from a nearby farm in Anambra State in Nigeria. It was allowed to ferment for 4-6 days. The seeds were selected mechanically, washed, parboiled for 10 minutes to soften the endocarp for easy removal and dried. The seeds were crushed, winnowed and milled into powder form.

\section{B. Oil Extraction}

Soxhlet extraction is recognized by the Association of Analytical Chemists (AOAC) as the standard method for crude fat analysis. Fat is extracted through repeated washing, or percolation, with an organic solvent under reflux in special glassware. Lipid extraction by Soxhlet is usually performed with polar solvents such as $n$-hexane. Since $n$-hexane is considered to be a hazardous air pollutant, interest in alternatives to $n$-hexane as an extraction solvent has been stimulated.

\section{EXPERIMENT}

The oil was extracted from $10 \mathrm{~g}$ seed flour samples in a Soxhlet AOAC (2000) with N-hexane, at $60^{\circ} \mathrm{C}-80^{\circ} \mathrm{C}$ respectively. The solvent was recovered by distilling off at a temperature of $80^{\circ} \mathrm{C}$. The process is repeated for Acetone, Ethanol, Petroleum Ether and Diethyl Ether and Conc. of Diethyl Ether respectively. The percentage of oil content of the seed was calculated from the weight of oil and weight of sample. Oil yield was calculated based on the oil weight. The same method was followed for the extraction with other solvents.

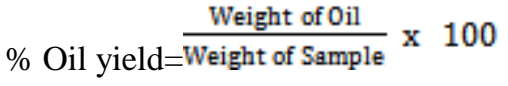




\section{RESULT AND DISCUSSION}

The oil extracted from the breadfruit seeds had a light yellow colour which may be due to the pigment extracted along with the oil. The odour of the oil is a characteristic of breadfruit and it resembles that of the seed. The oil remains liquid at room temperature and the oil content was given for the various solvents.

\section{Table 1: Weight of Oil Extracted}

\begin{tabular}{|l|l|}
\hline Solvents & Weight of Oil Extracted \\
\hline Ethanol & 0.02 \\
\hline N-hexane & 0.56 \\
\hline Acetone & 0.74 \\
\hline Petroleum Ether & 1.05 \\
\hline Diethyl ether & 1.5 \\
\hline Conc. Diethyl Ether & 1.502 \\
\hline
\end{tabular}

Using Equation 1 the percentage yield of the extracted oil is shown in Table 2 .

Table2: Percentage of Oil Extracted \%

\begin{tabular}{|l|l|}
\hline Solvents & Percentage of Oil Extract \\
\hline Ethanol & 0.2 \\
\hline N-hexane & 5.6 \\
\hline Acetone & 7.4 \\
\hline Petroleum Ether & 10.5 \\
\hline Diethyl ether & 15 \\
\hline Conc. Diethyl Ether & 15.02 \\
\hline
\end{tabular}

From Table 1, it is seen that the various extracting solvents yields different amount of oil. This is due to the extracting power of the solvent. Some solvents have high extracting power than others. This is shown in Fig. 1.

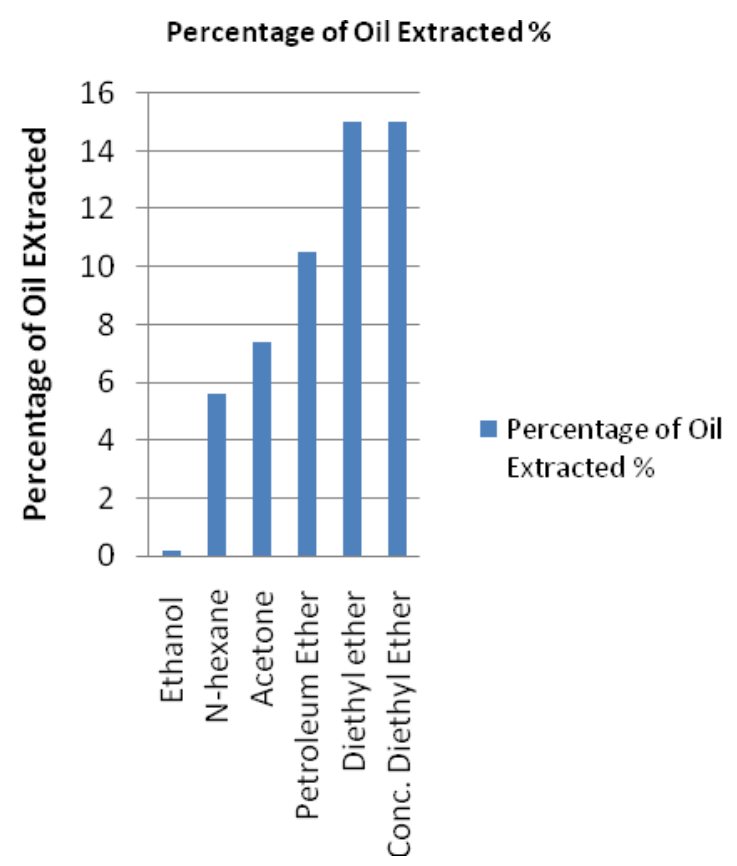

Figure 1: Effect of Solvent on the Oil yield of the Seed
From "Fig." 1 above there is a large difference that the amount of oil yielded by each of the extracting solvent differs. The difference between Diethyl ether and Conc. Diethyl Ether in terms of the oil yield showed that the concentration of a solvent has an effect on the yield of oil extracted.

\section{CONCLUSION}

From the result, it is evident that the choice and concentration of a solvent has an effect on the amount of oil extracted from the African Breadfruit seed; this is due the solvent power of the solvents. It could be recommended that an increase in the concentration of the solvent would yield a better volume of oil. This research also shows that vegetable oil industry could improve their process by choosing a solvent with high solvent power.

\section{REFERENCES}

[1] Sheehan, J.; Dunahay, T.; Benemann, J.; Roessler, P. A Look Back at the US Department of Energy's Aquatic Species Program: Biodiesel from Algae. NREL/TP-580-24190. U.S Department of Energy's Office of Fuels Development, Golden, CO, USA, 1998; pp. 1-325.

[2] Wan, P.J.; Hron, R.J.; Dowd, M.K.; Kuk, M.S.; Conkerton, E.J. Alternative hydrocarbon solvents for cottonseed extraction: Plant trials. J. Am. Oil Chem. Soc. 1995, 72, 661-664.

[3] Hanmoungjai, P.; Pyle, L.; Niranjan, K. Extraction of rice bran oil using aqueous media. J. Chem. Technol. Biotechnol. 2000, 75, 348-352.

[4] Anastas, P.; Warner, J. Theory and Practice; Oxford University Press: New York, NY, USA, 1998.

[5] OdoemelamS.A.Chemical composition and functional propertiesof conorphorn nut(Tetracarpidiumconorphorum) flour, IntJ.FoodSci.Technol., (2000). 38: 729 -734.

[6] Radziah W., Miradatul M.R., and Nurfadilah M.I.: Basic study on anti-bacterial properties of adenantherapavonina (saga) seed oil, IEEE Symposium, Engineering and industrial applications, Malaysia (2011)

[7] Wu H., Shi J., Xue S., Kakuda Y., Wang D., Jiang Y., Ye X., Li Y., Subramanian J. Essential oil extracted from peach (Prunuspersica) kernel and its physicochemical and antioxidant properties, LWT - Food Science and Technology, (2011), 44, 2032-2039.

[8] Ajiwe V.I.E., Umerie S. C., Okeke C. A. and Oburota V. N. Extraction and utilisation of cassava seed oil, Bioresource Technology, (1994), 47, 85-86.

[9] Zarnowski R., Suzuki Y., Expedient Soxhlet extraction of resorcinolic lipids from wheat grains. Journal of Food Composition and Analysis, (2004)17, 649-663.

[10] 10.Hamamre Z., Foerster S., Hartmann F., Kröger M., Kaltschmitt M., Oil extracted from spent coffee grounds as a renewable source for fatty acid methyl ester manufacturing, Fuel, (2012), 96, 70-76.

[11] Ahmad A. Optimization of soxhlet extraction of herbaleonuri using factorial design of experiment, International Journal of Chemistry, (2010), vol. 2.

[12] AOAC, Official Methods of Analysis; $14{ }^{\text {th }}$ Edition, Association of Official Analytical Chemists; Washington DC, USA (2000).

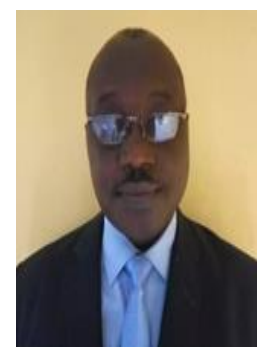

IPEGHAN JONATHAN OTARAKU was born on $3^{\text {rd }}$ of March, 1959 and attended the Volgograd Polytechnic Institute (now Technical University) from 1980 to 1985 and obtained the Masters of Science degree in Chemical Engineering (with distinction), specializing in Basic Organic and Petrochemical Engineering. I proceeded to Moscow Institute of Fine Chemical Technology (now Academy) in 1985 and obtained a Doctor of Philosophy $(\mathrm{PhD})$ degree in Chemical Engineering in 1990, specializing in Catalysis and Fine Chemical Engineering. I have published several research articles on Catalysis, Petrochemical Engineering, Environmental Engineering and 
World Journal of Innovative Research (WJIR)

ISSN: 2454-8236, Volume-6, Issue-3, March 2019 Pages 74-76

authored 2 books. I am also a holder of a Russian patent on production of succinic anhydride. I am a member of several professional bodies: American Institute of Chemical Engineers, Nigerian Society of Engineers, an elected member of the New York Academy of Sciences amongst others. A Registered Engineer, I have been a lecturer in the Department of Chemical Engineering of the University of Port Harcourt, Nigeria, where I am a Senior Lecturer. In 2003, I was elected to membership of Marquis Who's Who in Science and Engineering.

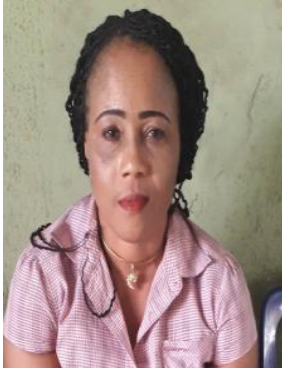

International Journals

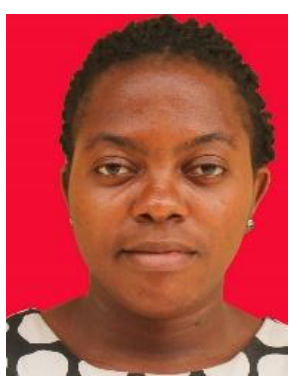

YIRAKPOA PATIENCE NWAMBO

EDUCATIONAL QUALIFICATIONS: Ph.D.

(In-view)University of Lagos, Akoka. M.Sc -Chemical Engineering- University of Lagos. Akoka.(June 2003).B.Tech. -Chemical/Petrochemical Engineering- Rivers State University of Science and Technology, Nkpolu. Port Harcourt (November, 1994). Diploma in Computer Studies (Dec 2001). West African School Certificate May/June 1987. PUBLICATIONS: I have co-authored several research articles in different

Engr. IshiomaLaureneEgun, holds a Masters' degree in Chemical Engineering from the University of Port Harcourt. I am a member of several professional bodies (Nigeria Society of Engineers, Nigeria Society of Chemical Engineers, Association of Professional Women Engineers of Nigeria, a registered engineer (R.Eng. 46344). I have written numerous journal articles published in diverse journal. My interests are in Renewable Energy, bio fuel and Environmental Conservation. 